\title{
KATA SERAPAN MAKANAN DAN MINUMAN DARI BAHASA CINA
}

\author{
Assa Rahmawati
}

\begin{abstract}
Abstrak
Bukti kontak budaya antara bangsa Indonesia dengan Cina, selain terlihat dari sejumlah artefak kuno, juga nampak dari sejumlah kosakata dalam Bahasa Indonesia baik tulis maupun lisan. Penelitian tentang kosakata dalam Bahasa Indonesia yang berasal dari bahasa asing, termasuk kosakata yang berasal dari Bahasa Cina, telah dilakukan oleh Russell Jones. Hasil penelitiannya telah dibukukan dalam Loan Words in Indonesian and Malay. Penelitian tersebut mencatat sekitar 1.100 kosakata dari bahasa Cina yang diserap ke dalam Bahasa Indonesia yang tersebar dalam berbagai medan makna, antara lain medan makna makanan dan minuman yang akan dipaparkan dalam makalah singkat ini.
\end{abstract}

\section{Kata Kunci}

\begin{abstract}
The evidence of cultural link between Indonesia and China does not always could be seen from classical artefacts only but also from the existence of some vocabularies in the written and oral language in Indonesian language (Bahasa Indonesia). Survey concerned with the vocabularies in Indonesian language which derived from foreign language, including those words derived from Chinese language, was conducted by Russell Jones. The result had been written in a book called 'Loan Words in Indonesian and Malay'. The survey had recorded around 1.100 words in Chinese language which had been borrowed by the Indonesian language and had spread out in differnt kinds of aspect of meaning, including the aspect of meaning related to food and beverage, which will be described in this paper.
\end{abstract}

\section{Keywords}

\section{PENGANTAR}

Bangsa Indonesia sejak dulu telah mengadakan kontak dengan bangsa lainnya, antara lain dengan bangsa Cina. Kontak pertama bangsa Indonesia dengan bangsa Cina terjadi saat dinasti Han berkuasa (201sM-220M)․ Hal ini terlihat dari sejumlah artefak kuno, seperti prasasti, guci antik dan sebagainya di Sumatra, Kalimantan, dan

\footnotetext{
1 Menurut 后汉书 atau catatan yang terjadi pada masa dinasti Han Timur, tahun $131 \mathrm{M}$ bangsa Indonesia telah mencapai daratan Cina. Menurut Catatan Negara Buddha 佛国记, seorang pendeta Buddha yang bernama Fa Xian 法显 adalah orang Cina pertama datang ke Indonesia pada tahun $414 \mathrm{M}$ dengan menumpang kapal dagang India.
} 
Jawa. Selain itu, tanda-tanda adanya kontak dengan bangsa asing juga nampak dalam sejumlah kosakata dalam bahasa Indonesia yang kalau ditelusuri asal usulnya berasal dari bahasa lain, seperti Bahasa Sanskerta, Bahasa Arab, Bahasa Persia, Bahasa Hindi Bahasa Tamil, Bahasa Cina, Bahasa Portugis, Bahasa Belanda, Bahasa Inggris, dan Bahasa Jepang. Kata-kata seperti sampan, becak, kemoceng, tahu adalah beberapa contoh kata yang berasal dari Bahasa Cina.

Penelitian mengenai kosakata bahasa asing yang diserap ke dalam Bahasa Indonesia antara lain dilakukan oleh Russell Jones². Penelitian oleh Russell Jones ini mendata kosakata yang berasal dari bahasa asing yang diserap dalam Bahasa Indonesia, antara lain dari Cina. Dalam penelitian ini tercatat ada 10 bahasa dan dialek yang berasal dari Bahasa Cina yang diserap dalam Bahasa Indonesia ${ }^{3}$ dengan jumlah sekitar 1.100 kosakata yang tersebar dalam berbagai ranah. Makalah ini hanya membahas kosakata yang berkaitan dengan makanan dan minuman yang berasal dari Bahasa Cina yang ada dalam penelitian tersebut di atas. Dalam makalah ini, selain deskripsi tentang acuan kosakata, juga akan dicantumkan bunyi yang telah diterima dan telah disesuaikan secara fonetis saat diserap ke dalam Bahasa Indonesia, serta makna karakter Cinanya.

\section{MAKNA SEMANTIS KATA LEKSIKAL}

Setiap kata mengandung makna di dalamnya. Kalau diteliti lebih jauh, setiap kata memiliki jangkauan makna. Misalnya makna yang terkandung pada kata 'membawa' antara lain (i) ada aktivitas (ii) aktivitas dilaksanakan oleh manusia (iii) orang yang melaksanakan kegiatan menggunakan tangan, bahu, atau kepala (iv) ada benda yang menjadi sasaran kegiatan (v) kegiatan itu dilaksanakan dari satu tempat ke tempat lain. Kelima unsur makna yang disebutkan di atas merupakan jangkauan makna yang dimiliki kata 'membawa'. Jangkauan makna inilah yang disebut medan makna suatu kata. Dengan demikian, banyak kata lain yang dapat dimasukkan dalam medan makna kata 'membawa', misalnya memikul, menggendong, menjinjing, menjunjung. Kata-kata tersebut dikatakan sebagai kelompok kata yang memiliki medan makna yang sama (Pateda, 2001: 255). Menurut Kamus Linguistik, medan makna merupakan bagian dari sistem semantik bahasa yang menggambarkan bagian dari bidang kehidupan atau realitas dalam

\footnotetext{
2 Rusell Jones adalah doktor dari School of Oriental \&African Studies, London. Ia merupakan salah satu anggota proyek penelitian etimologi Bahasa Indonesia, selain Prof. L. Santa Maria dari Istituto Universitario Orientale, Naples, Dr. Denys Lombard dari École Française d’Extrême Orient, Paris, Dr. C.D. Grijns dari University of Leiden, Prof. Harimurti Kridalaksana dari Universitas Indonesia, Prof. J.W.de Vries, University of Leiden. Hasil penelitian ini kemudian diterbitkan dengan judul Loan-Words in Indonesian and Malay tahun 2007 dengan Russell Jones sebagai editor utama. Penelitian ini hanya mendata kosakata Bahasa Indonesia yang berasal dari bahasa asing, tidak mencakup kosakata yang berasal dari bahasa daerah, seperti Bahasa Jawa, Sunda.

${ }^{3} 10$ bahasa dan dialek dari Cina adalah Amoy (Xiamen), Tsoanchiu/Chuanchow (Quanzhou), Chiangchiu/ Changchou (Zhangzhou), Teochew/Swatow (Chaozhou), Hokchiu/Foochow (Fuzhou), Ningpo (Ningbo), Tong'an (Tongan), Canton (Guangdong), Hakka/Kheh (Kejia), Mandarin (Putonghua) (Jones: xxviii).
} 
alam semesta tertentu dan yang direalisasikan oleh seperangkat unsur leksikal yang maknanya berhubungan (Kridalaksana, 1982: 105). Mengenai medan makna, Nida (1974: 174) menyebutkan 'semantic domain consists simply of meanings which have common semantic components'. Selanjutnya unsur-unsur medan makna yang sama tersebut dikelompokkan menjadi (i) entitas atau objek (ii) kegiatan (iii) abstraksi (iv) penghubung.

Medan makna yang akan dipaparkan mencakup medan makna makanan dan minuman. Menurut Kamus Besar Bahasa Indonesia (KBBI, 2002: 701) yang dimaksud dengan makanan adalah 'segala sesuatu yang dapat dimakan (seperti penganan, lauk pauk, kue)'. Dengan demikian, medan makna makanan dapat dipisahkan menjadi lauk pauk, makanan kecil, atau kue. Baik lauk pauk maupun makanan kecil diolah dari berbagai macam bahan makanan. Bahan makanan menurut KBBI adalah 'bahan yang dapat dijadikan makanan, seperti beras, terigu, jagung, ubi'(2002: 87). Selain bahan makanan, bumbu ${ }^{4}$, sayur ${ }^{5}$, dan buah ${ }^{6}$ juga digunakan dalam membuat atau mengolah lauk pauk atau makanan kecil. Oleh karena itu, kosakata bahan makanan, bumbu, sayur, dan buah-buahan, juga termasuk dalam medan makna makanan. Masih menurut KBBI, minuman adalah 'barang yang diminum'(2002: 746). Dengan demikian, medan makna minuman mengacu pada sesuatu yang dapat diminum.

Makalah ini selanjutnya akan memaparkan sejumlah kosakata Bahasa Indonesia yang berasal dari Bahasa Cina bermedan makna makanan dan minuman yang ada dalam buku Loan-Words in Indonesian and Malay. Pemaparan ini dimulai dari kosakata yang termasuk dalam medan makna lauk pauk, makanan kecil, bahan makanan, bumbu, sayur-sayuran, buah-buahan, dan minuman.

\section{LAUK PAUK}

Dari daftar kosakata bermedan makna makanan dalam buku Loan Words in Indonesian and Malay ada sejumlah kosakata yang dapat dikatagorikan sebagai lauk pauk. Menurut KBBI lauk pauk mempunyai makna 'berbagai-bagai lauk', sedangkan lauk adalah 'daging atau ikan dan sebagainya (selain sayur) yang dimakan sebagai teman nasi'(2002: 644). Berdasarkan makna yang dikandung dalam kosakata lauk pauk seperti yang disebutkan di atas, ada sejumlah kosakata yang masuk dalam medan makna lauk pauk, antara lain bakhu, bakmi, capcai, fuyongbak, hung siou ie, kimlo, kolobak, koloké, kuluyuk, lomi, mun tahu, puyonghai, sékbak, siobak, swike.

Bakhu 肉脯 adalah makanan yang terbuat dari daging babi suwir yang

\footnotetext{
4 Bumbu adalah berbagai jenis hasil tanaman yang berbau harum atau sedap seperti jahe, kunyit, lengkuas, pala, merica yang digunakan untuk menyedapkan masakan (KBBI, 2002: 175).

5 Menurut KBBI yang dimaksud dengan sayur adalah daun-daun (seperti sawi), tumbuh-tumbuhan (taoge), polong atau bijian (kapri, buncis) dsb yang dapat dimasak (2002: 1006).

6 Yang dimaksud dengan kata buah di sini adalah bagian tumbuhan yang berasal dari bunga atau putik (KBBI, 2002: 166)
} 
dikeringkan. Bak 肉 berarti 'daging'. Daging yang dimaksud di sini adalah daging babi? Menurut Kamus Besar China-Indonesia hu 脯 berarti 'dendeng' (1995: 261). Menurut KBBI dendeng adalah 'daging sayatan yang dirempahi dan dikeringkan'. Bakhu dibuat dari daging babi yang direbus dengan kecap sampai lunak. Setelah lunak, kemudian disuwirsuwir, lalu disangrai sampai kering. Dengan demikian, bakhu bukanlah dendeng yaitu daging babi yang dipotong tipis, dibumbui, lalu dikeringkan, melainkan daging babi yang direbus dengan kecap sampai lunak, lalu disuwir-suwir dan disangrai sampai kering. Bakhu lebih mengacu pada kata abon yaitu 'makanan berbahan daging rebus yang diserat-seratkan, dibumbui, kemudian digoreng' (KBBI, 2002: 2).

Bakmi 肉麵 terdiri dari bak 肉 berarti 'daging' dan $m i$ 麵 berarti 'mi'. Menurut KBBI bakmi adalah 'makanan yang bahannya dari tepung (terigu dsb), bentuknya panjangpanjang seperti tali' (2002: 94). Penjelasan kata bakmi dalam KBBI tidak menyebutkan adanya penambahan tumisan daging pada masakan bakmi. Dalam kenyataannya masakan bakmi ini biasanya dihidangkan dengan dibubuhi tumisan daging (ayam, sapi atau babi). Ada juga yang menyebut masakan ini bakmi ayam. Penyebutan bakmi ayam ini agak berlebihan karena makna yang dikandung kata bakmi sudah mencakup mi ditambah tumisan daging ayam. Kadang bakmi ditambah bakso atau pangsit yang direbus atau digoreng. Karena ditambah dengan bakso atau pangsit, nama masakan ini menjadi bakmi bakso, bakmi pangsit, atau bakmi bakso pangsit karena ada bakso dan pangsit. Bakmi juga seringkali disajikan dengan cara digoreng, menjadi bakmi goreng. Bagi sebagian orang, bakmi goreng juga dapat menjadi lauk atau dapat dimakan dengan nasi. Kata bakmi seringkali disingkat menjadi 'mi' menjadi mi ayam, mi bakso, mi pangsit, mi goreng. Meskipun hanya disebut mi bakso, mi pangsit, tetapi kedua masakan mi ini tetap dibubuhi tumisan daging.

Capcai 雜菜 menurut KBBI adalah 'makanan yang terdiri atas sayur (wortel, sawi hijau, bunga kol, dsb) ditambah bakso, kembang tahu, udang dsb, dan diberi bumbu tertentu (2002: 194). Masakan ini sesuai dengan namanya karena cap 雜 berarti 'aneka rupa', cai 菜 berarti 'sayuran'. Capcai disajikan dalam dua pilihan, yaitu capcai goreng dan capcai kuah. Pada dasarnya kedua macam capcai ini sama yaitu masakan yang terdiri dari beraneka sayuran, jamur, ditambah bakso, irisan daging ayam, udang. Capcai goreng berkuah lebih sedikit dibandingkan capcai kuah ${ }^{8}$. Makanan ini berkuah sedikit kental karena diberi sedikit tepung maizena atau tepung tapioka.

Puyonghai 芙蓉蟹 menurut KBBI adalah 'masakan Cina berupa telur dadar yang bahannya dari sayuran, udang cincang, telur, dikocok dengan garam, dibumbui

\footnotetext{
7 Menurut Putonghua Minnan Fangyan Zidian (Kamus Bahasa Mandarin-Bahasa Daerah Min Selatan) 肉: 转指猪肉 (khusus mengacu pada daging babi) (1982: 661).

8 Dalam Indonesian-Chinese Cooking, selain kuah lebih banyak, jenis sayuran dalam capcai kuah lebih banyak daripada capcai goreng (Hadibroto, 2011: 151,152).
} 
dengan lada dan vetsin serta diberi saus'(2002: 915). Puyong 芙蓉 berarti 'teratai', hai 蟹 berarti 'kepiting'. Hadibroto dalam buku Indonesian-Chinese Cooking mengatakan bahwa puyonghai adalah 'telur dadar yang isinya daging kepiting, rebung, daun bawang' (2011: 145). Telur dadar tersebut disiram saus asam manis saat disajikan. Marahimin dalam buku Masakan Peranakan Tionghoa Semarang menyebutkan bahwa puyonghai adalah 'telur dadar yang isinya udang, daging kepiting, rebung, kapri, sedikit tepung terigu', disajikan dengan saus asam manis (2011: 72). Pada prinsipnya, KBBI, Hadibroto, maupun Marahimin menyatakan hal yang sama tentang puyonghai yaitu 'telur dadar yang isinya daging kepiting atau udang'. KBBI, Hadibroto, dan Marahimin tidak menyebut fuyongbak 芙蓉肉. Karakter Cina yang terakhir dari kata fuyongbak adalah 肉 bak yang berarti 'daging babi', sedangkan karakter Cina yang terakhir dari kata puyonghai adalah 蟹 hai yang berarti 'kepiting'. Dengan demikian, perbedaan fuyongbak dan puyonghai terletak pada jenis daging yang dimasukkan dalam kocokan telur. Isi atau campuran telur pada fuyungbak adalah daging (babi), sedangkan campuran pada puyonghai adalah daging kepiting.

Hung siou ie 紅燒魚 atau angsiohi dalam Bahasa Hokkian terdiri atas tiga karakter yaitu 紅, 燒, dan 魚. Hung atau ang 紅 berarti 'merah', siou atau sio 燒 'masak', ie atau hi 魚 'ikan', adalah makanan yang terbuat dari daging ikan yang digoreng dengan tepung, kemudian dicampur dengan kuah kental asam manis berwarna merah yang berasal dari saus tomat ${ }^{9}$. Makanan lain yang dicampur saus merah adalah kolobak 古老肉, koloké 古老 雞, dan kuluyuk 古老肉. Kalau diperhatikan, dua karakter Cina pada kata kolobak, koloke, kuluyuk adalah sama, yaitu 古老 yang artinya 'kuno'. Karakter Cina yang terakhir pada kata kolobak dan kuluyuk sama, yaitu 肉 bak yang artinya 'daging', sedangkan karakter Cina terakhir pada kata koloke adalah 雞 ké yang artinya 'ayam'. Dengan demikian, kolobak maupun kuluyuk berbahan dasar daging babi ${ }^{10}$, sedangkan koloké berbahan dasar daging ayam. Ketiganya adalah masakan yang terbuat dari daging babi atau ayam yang digoreng tepung, kemudian disiram dengan kuah kental berwarna merah yang rasanya asam manis. Namun, pada beberapa rumah makan Cina ada yang menggabungkan kata kuluyuk dengan ayam menjadi ayam kuluyuk yang mengacu pada masakan yang terbuat dari ayam goreng tepung dicampur kuah kental asam manis yang berwarna merah.

Kimlo 錦珯 ${ }^{11}$ adalah sejenis makanan berkuah seperti sup yang terdiri dari campuran jamur kuping, sedap malam, udang, bakso ikan, wortel, sohun, telur puyuh

\footnotetext{
9 Menurut Hiang Marahimin dalam bukunya Masakan Peranakan Tionghoa Semarang, warna merah pada hidangan ini aslinya berasal dari angkak (2011: 64).

${ }^{10}$ Menurut Russell Jones (ed.) bak merupakan lafal bahasa Hokkian untuk karakter 肉, karakter 肉 dilafalkan yuk dalam bahasa Kanton.

11 錦 (kim) 'brokat', untuk karakter 珯 (lo) tidak ditemukan artinya di kamus.
} 
rebus. Kuah kimlo ini adalah kaldu ayam yang diperoleh dengan merebus daging ayam hingga lunak. Setelah kuah kaldu dibumbui, barulah isi masakan kimlo, seperti jamur kuping, sedap malam, udang, bakso ikan, wortel dimasukkan ke dalam kuah. Terakhir baru dimasukkan sohun dan telur puyuh yang telah direbus. Jenis masakan lain yang berkuah banyak adalah soto 燒肚12. so 燒 'masak', dan to 肚 'babat'. Kuah makanan ini dimasak tersendiri. Kuah soto ini juga adalah kaldu ayam atau daging sapi, bukan babat. Selanjutnya, ketika soto akan disajikan, potongan daging sapi atau suwiran ayam, kentang, taoge disiram kuah soto, lalu dibubuhi bawang goreng.

Lomi 泪麵, lo 澞 'merebus (ayam, bebek) dengan kecap dan bumbu' dan $m i$ 麵 'mi'. Jadi, lomi adalah mi yang dimasak dengan ayam atau bebek yang diberi kecap dan bumbu. Mi yang digunakan dalam masakan ini adalah mi yang besar dan tebal. Mi besar dan tebal ini kemudian dimasak dalam tumisan udang, ayam, bakso dan sayuran ${ }^{13}$. Masakan ini berkuah agak kental karena diberi tepung maizena. Mun tahu 燜豆腐, mun 燜 'memasak di atas api kecil', dan tahu 豆腐 'tahu'. Dengan demikian, mun tahu berarti tahu yang dimasak dengan api kecil. Mun tahu adalah masakan yang terbuat dari tahu yang dipotong dadu-dadu kecil dan dimasak dengan kuah agak kental yang berisi campuran udang cincang dengan daging ayam atau babi cincang. Kuah masakan ini agak kental karena dibubuhi tepung maizena.

Masakan lain yang berbahan dasar daging babi adalah sekbak dan siobak. Sékbak 熟肉, sek 熟 'matang', bak 肉 'daging', adalah masakan yang terdiri dari daging babi, jerohan babi ${ }^{14}$, tahu, sawi asin yang direbus dengan kecap asin, bumbu ngohiang, dan pekak. Saat disajikan, daging babi, jerohan babi, tahu, sawi asin dipotong-potong dan ditata di atas piring atau mangkuk, kemudian disiram dengan kuah rebusannya. Siobak 燒肉, sio 燒 'masak', dan bak 肉 'daging', adalah daging babi berkulit yang dipanggang. Karena dipanggang, maka warna daging pada masakan ini putih kecoklatan. Tetapi ada pula daging babi panggang yang berwarna merah. Warna merah tersebut berasal dari penggunaan angkak sebagai tambahan bumbu. Daging babi panggang yang berwarna merah disebut casiobak. Siobak biasanya menjadi lauk yang dimakan bersama acar atau kuah sayur sawi asin.

Swiké 水雞, swi 水 artinya 'air' dan ké 雞 'ayam' sehingga gabungan maknanya menjadi 'ayam air', menurut KBBI adalah 'daging katak hijau yang dibuat menjadi berbagai macam masakan' (2002: 1113). Dengan demikian, masakan yang terbuat dari

\footnotetext{
${ }^{12}$ Ibid. hal. 106 yang mengutip dari Dennys Lombard 'Nusa Jawa: Silang Budaya' bahwa caudo, masakan berkuah yang isinya potongan babat dan lobak, adalah makanan Cina yang pertama kali populer di Semarang dan merupakan cikal bakal soto, taoto, saoto, coto dan aneka soto lainnya.

${ }^{13}$ Hiang Marahimin, Op.Cit., hal. 112 menyebutkan dulu, lomi disajikan untuk ulang tahun karena tebal dan tidak mudah putus. Ada kepercayaan yang tebal itu makmur dan yang panjang itu panjang umur.

14 Jerohan bisa berupa lidah, telinga, usus besar/toa han, limpa dan jantung. Semua sudah harus dalam keadaan bersih dan matang, lalu diempukkan bersama daging (Hadibroto, 2011: 72).
} 
daging katak disebut swike ${ }^{15}$. Beberapa masakan yang terbuat dari daging katak hijau misalnya swike goreng. Pada masakan ini, daging kodok digoreng terlebih dahulu, kemudian dimasak sebentar dengan saus yang terdiri dari kecap asin, kecap manis, dan saus tomat. Daging kodok juga bisa dimasak dengan tauco disebut swike masak tauco, atau dimasak dengan sawi asin menjadi swike ca sayur asin.

\section{MAKANAN KECIL}

Selain jenis lauk, juga terdata beberapa kosakata makanan kecil atau kue 粿, seperti bacang, bépang, cang, kué cang, kué ku, muaci, bakpao, paupau, pia, bakpia, songpia, ciupia, cupiah, tiongciupia, cakue, pangsit, bakwan, lumpia, siomai, mipan, niénkao.

Bacang 肉粽 adalah penganan seperti lontong, terbuat dari beras atau ketan yang diisi daging yang ditumis dengan jamur ditambah bumbu kecap. Sebagian orang menambah isi bacang dengan kuning telur asin pada makanan ini. Meskipun ada unsur bak 肉 'daging babi', bakcang yang berisi daging sapi atau ayam tetap disebut bakcang. Cang 粽 ‘sejenis makanan' atau sering disebut dengan kue cang ${ }^{16}$ adalah penganan yang terbuat dari ketan tanpa isi yang dimakan dengan srikaya atau gula pasir maupun gula jawa yang sudah dicairkan. Penganan ini juga disebut kicang. Dulu, bacang atau kue cang dibuat setahun sekali pada perayaan Pecun untuk menghormati Khut Goan (Qu Yuan $)^{17}$, sekarang bacang bisa diperoleh setiap saat tanpa harus menunggu perayaan Pecun.

Kué Ku 粿龜, kue 粿 'kue', dan ku 龜 'kura-kura', adalah kue basah terbuat dari tepung beras pulut, dicetak dalam bentuk lonjong cembung, berisi tepung kacang hijau, biasanya berwarna merah, diberi alas daun pisang (KBBI, 2002: 608). Kue Ku berbentuk seperti kura-kura yang merupakan simbol panjang umur bagi orang Cina. Kue $\mathrm{Ku}$ sering dijadikan sajian di meja sembahyang atau menjadi isi hantaran untuk merayakan kelahiran bayi. Warna merah pada kue ku berasal dari bubuk angkak atau pewarna makanan (Marahimin, 2011: 140). Muaci 麻糍, mua 麻 ‘wijen', dan ci 糍 'penganan dari

${ }_{15}$ Hiang Marahimin, Op.Cit., hal 78 menyebutkan bahwa daging kodok yang paling bagus berasal dari Purwodadi. Masakan swike yang terkenal pun disebut Swike Purwodadi.

${ }_{16}$ Menurut KBBI cang adalah penganan yang dibuat dari nasi ketan yang dibumbui, diisi daging cacah, dibungkus dengan daun bambu seperti lepat dan dikukus. Beberapa informan menyatakan bahwa cang hanya terbuat dari ketan tanpa isi yang dibungkus daun bambu. Makanan ini biasanya dimakan dengan gula jawa atau gula pasir yang sudah dicairkan.

${ }^{17} \mathrm{Qu}$ Yuan adalah seorang penyair sekaligus perdana menteri kerajaan Chu yang jujur dan bijaksana pada masa negara berperang. Banyak pejabat lain iri padanya sehingga dia sering difitnah dan akhirnya diasingkan. Qu Yuan merasa sangat terpukul terutama setelah kerajaan Chu dijatuhkan oleh kerajaan kerajaan Qin. Peristiwa ini menyebabkan Qu Yuan menceburkan diri ke dalam sungai. Warga berusaha mencari dengan menggunakan perahu sambil menabuh tambur dan genderang, tapi jasad Qu Yuan tidak ditemukan juga. Selanjutnya, orang-orang sehingga melempar nasi berbungkus daun ke sungai untuk menghormati rohnya sekaligus mohon agar binatang sungai tidak mengganggu jenazahnya. Kesibukan warga mencari jenasah QuYuan dengan perahu serta melempar makanan berbungkus ke dalam sungai menjadi cikal bakal perlombaan perahu Naga serta kebiasaan membuat bacang. 
ketan', atau dikenal sebagai kue moci adalah kue yang terbuat dari tepung ketan yang diadon dengan santan kental, garam, dan gula pasir. Penganan yang berbentuk bulat ini sebenarnya berasal dari Jepang. Tetapi, karena banyak pengusaha kue moci ditemui di daerah Sukabumi, maka kue moci dianggap sebagai makanan khas kota Sukabumi. Awalnya kue moci dikenal hanya memiliki dua rasa, yaitu kue moci tanpa isi dan kue moci isi kacang. Belakangan, isi kue moci lebih bervariasi, seperti rasa moka, jahe, keju, wijen, vanila, pandan hingga rasa buah-buahan seperti durian, nangka, melon, stroberi, pisang ambon ${ }^{18}$. Bakpao 肉包 ${ }^{19}$, bak 肉 berarti 'daging', dan pao 包 berarti 'bungkus', adalah penganan seperti roti, berbentuk seperti tempurung tertelungkup, dikukus, terbuat dari terigu dengan isi daging atau kacang hijau (KBBI, 2002: 94). Daging yang digunakan sebagai isi bakpao tidak hanya dari daging babi, tetapi juga dari dari daging sapi atau ayam. Selain daging atau kacang hijau, seringkali cokelat juga dipakai menjadi isi bakpao. Apa pun yang menjadi isi bakpao, penganan tersebut tetap disebut bakpao.

Menurut Kamus Bahasa Mandarin-Bahasa Daerah Min Selatan, pia 餅 adalah 'sebutan untuk makanan dari tepung terigu yang dipanggang atau dikukus, umumnya berbentuk pipih dan bundar' (1982: 51). Selanjutnya ada bakpia 肉餅, bak 肉 'daging', dan pia 餅 'penganan dari terigu', yang menurut KBBI adalah 'kue kering, berbentuk bundar agak pipih, bagian luarnya mudah remuk, terbuat dari terigu dengan isi kacang hijau' (2002: 94). Selain kacang hijau dan jenis kacang lainnya, isi bakpia ada yang berupa keju, coklat, atau durian. Jarang atau bahkan tidak pernah ditemui pia isi daging. Hal ini tidak sesuai dengan namanya bakpia 肉餅 atau pia isi daging. Selain bakpia, juga ada pia yang awalnya disajikan pada perayaan pertengahan musim gugur setiap tanggal 15 bulan 8, yaitu ciupia atau cupiah 秋餅, ciu 秋 'musim gugur', dan 餅 pia 'penganan dari terigu'. Ciupia adalah kependekan dari kata tiongciupia 中秋餅, tiong 中 'tengah', ciu 秋 'musim gugur', dan pia 餅 'penganan dari terigu'. Tiongciupia sering disebut sebagai kue bulan. Ukuran tiongciupia lebih besar dibandingkan bakpia. Tiongciupia terbuat dari terigu, gula, kuning telur, dan minyak atau margarin. Dulu, kue bulan yang tradisional diisi daging babi dan tangkue (manisan labu air). Kini, kue bulan dibuat halal dengan isi kacang hijau, kacang merah, biji teratai,cokelat, keju, kurma, durian, teh hijau. Kue bulan yang lebih mewah diisi dengan kuning telur asin yang melambangkan persatuan dan kesempurnaan seperti bulan pada tanggal limabelas (Marahimin, 2011: 174).

Ada lagi kue songpia 春餅, song 春 'musim semi', dan pia 餅 'penganan dari terigu', adalah kue yang bentuknya seperti lumpia kecil-kecil. Kue ini terbuat dari kulit lumpia yang dipotong kecil. Kulit lumpia ini digunakan untuk membungkus abon atau udang

\footnotetext{
18 Bisnisukm.com/kue-moci-potensi-daerah-sukabumi.html.

19 Dalam daftar kosakata medan makna makanan juga tercantum kata paupau atau paupao 包包 yang didefinisikan sebagai ' steamed stuffed bun'. Dengan penjelasan seperti ini, paupau atau paupao adalah sama dengan bakpao.
} 
kering yang menjadi isi kue songpia. Niénkao 年糕, nien 年 ‘tahun', dan kao 糕 ‘penganan', atau sering disebut dodol cina atau kue keranjang adalah kue yang selalu ada setiap perayaan tahun baru Imlek. Kue ini biasanya diletakkan di meja abu leluhur. Pada malam Cap Go $\mathrm{Meh}^{20}$ kue ini baru diturunkan dari atas meja abu leluhur, kemudian digoreng serta disantap bersama dengan harapan agar tahun yang akan datang akan manis seperti manisnya kue keranjang (Marahimin, 2011: 160). Kue yang ada di tahun baru Imlek ini dibuat dengan menggunakan keranjang kecil yang dialasi daun pisang sebagai pembungkus kue. Oleh karena itu disebut kue keranjang. Sekarang, plastik bening lebih sering digunakan sebagai pembungkus kue keranjang (Marcus, 2003: 74).

Cakue 炒粿 yang terdiri atas suku kata ca 炒 'goreng', dan kue 粿 'kue' adalah penganan yang digoreng yang terbuat dari adonan tepung, ragi, soda kue. Bentuknya panjang-panjang. Cakue bisa dimakan begitu saja seperti makanan kecil atau sebagai campuran bubur ayam. Sebelum dimakan dengan bubur, cakue dipotong kecil-kecil terlebih dahulu. Pangsit 扁食, pang 扁 'gepeng, pipih', dan sit 食 'makanan', adalah makanan yang terbuat dari daging cincang yang dibungkus dengan selaput yang terbuat dari adonan tepung terigu, digoreng, atau direbus' (KBBI, 2002: 824). Daging yang digunakan sebagai isi pangsit sebenarnya adalah daging babi yang dicampur dengan udang dan sayuran. Penggunaan daging babi sebagai isi pangsit kadang diganti dengan daging ayam yang juga dicampur dengan udang. Pangsit bisa direbus atau digoreng. Pangsit rebus umumnya dihidangkan dalam kuah kaldu. Selain itu, juga dikenal pangsit tanpa isi. Pangsit ini hanyalah kulit pangsit dari adonan tepung terigu yang digoreng, biasanya digunakan untuk campuran mi ayam. Lumpia atau lunpia 嫰餅, lun 嫰 'lembut, empuk', dan pia 餅 'penganan dari terigu', menurut KBBI adalah 'penganan berupa dadar yang diisi daging, rebung, dsb, lalu digulung dan biasanya digoreng' (2002: 688). Orang Semarang menyebut lunpia, bukan lumpia. Makanan yang mengandalkan rebung muda yang renyah dan tidak berbau, ditambah udang, ayam dan pihi sebagai isinya telah menjadi ikon kuliner kota Semarang (Marahimin, 2011: 128). Karena isi lumpia sudah matang, makanan ini dapat pula disantap tanpa perlu menggorengnya lagi. Lumpia yang dimakan tanpa perlu menggorengnya lagi disebut lumpia basah.

Bakwan 肉丸 menurut KBBI adalah 'makanan yang terbuat dari jagung muda dsb yang dilumatkan, dicampur dengan tahu atau udang, kemudian diadon bersama telur dan tepung terigu dan digoreng' (2002: 95). Bakwan seperti ini merupakan salah satu jenis makanan gorengan selain tahu dan tempe goreng, dimakan dengan cabai rawit atau sambal pecel. Makanan ini tidak sama dengan bakwan Malang. Bakwan Malang adalah makanan berkuah dengan isi bakso, pangsit rebus atau goreng serta sedikit mi.

\footnotetext{
${ }^{20}$ Cap Go Meh 十五冥, cap 十 sepuluh', go 五 'lima', meh 冥 'gelap' atau malam kelima belas bulan pertama merupakan penutup seluruh rangkaian perayaan Tahun Baru Imlek. Perayaan ini jatuh pada hari kelima belas yaitu saat bulan purnama pertama dalam tahun yang baru.
} 
Kalau dilihat dari makna harafiahnya, bakwan terdiri atas bak 肉 'daging' dan wan 丸 'benda bulat dan kecil'. Dengan demikian, bakwan 肉丸 adalah bakso yang terbuat dari daging babi $^{21}$.

Siomai 燒賣, terdiri dari sio 燒 'masak', dan mai 賣 'menjual'. Dengan demikian, siomai adalah makanan yang dijual saat masih dimasak. Makanan kecil ini terbuat dari kulit lumpia yang di dalamnya berisi campuran daging ayam dan udang. Semula, isi siomay adalah daging babi. Kemudian, bagian isi yang semula daging babi diganti dengan ikan tenggiri, ayam, udang, kepiting, atau campuran daging ayam dan udang. Setelah isi siomay terbungkus rapih dalam kulit lumpia, makanan ini kemudian dikukus sampai matang, lalu dimakan selagi panas dengan saus kacang atau saus pedas manis. Di beberapa restoran, siomai dijajakan berkeliling dengan cara menatanya di dalam kukusan bambu yang diletakkan di atas pemanas.

Bépang atau bipang 米芳, terdiri dari bi 米 yang berarti 'beras' dan pang 芳 'wangi, harum, adalah penganan yang terbuat dari nasi yang dijemur sampai kering. Nasi kering ini lalu dicampur dengan adonan gula jawa dan dibentuk segi empat lalu digoreng. Mipan 麵板, terdiri dari mi 麵 'tepung' dan pan 板 'papan', adalah kue berbahan dasar tepung beras yang dicampur dengan air khi, yaitu air abu batang padi, dan bahanbahan lainnya lalu dikukus hingga matang. Selanjutnya, makanan ini disajikan dengan saus yang terbuat dari campuran gula merah, kecap manis, minyak bawang putih dan rajangan halus bawang putih yang digoreng hingga renyah.

\section{BAHAN MAKANAN}

Selain kosakata tentang makanan yaitu sesuatu yang dapat dimakan, ada beberapa kosakata yang mengacu pada bahan makanan atau bahan yang dapat dijadikan makanan. Sebagian besar kosakata bahan makanan yang tercatat adalah bahan makanan yang diawetkan, misalnya haysom 海參, hay 海 'laut', dan som 參 'ginseng', atau 'teripang', 'timun laut'. Haysom bertekstur kenyal dan sangat menyerap bumbu. Sebagai bahan makanan yang berasal dari laut, haysom kaya akan protein dan rendah lemak. Haysom yang diawetkan berwarna hitam abu-abu dan awet bertahun-tahun jika disimpan di tempat kering. Sebelum diolah, haysom kering harus dicuci bersih, direndam semalaman, lalu dimasak dengan api kecil selama empat jam hingga warnanya berubah kecoklatan (Marahimin, 2011: 178). Bahan makanan ini biasanya digunakan untuk campuran masakan seperti capcai. Bahan makanan lain yang dikeringkan adalah hipiau atau hiepio 魚鳔, $h i$ 魚 'ikan', dan pio 鳔 'gelembung renang'. Hipiau adalah perut atau kantung udara ikan croaker (miichthys miiuy). Hipiau kering sering digunakan untuk campuran sup hipiau. Untuk masakan ca atau berkuah sering pula digunakan hipiau

${ }^{21}$ Yang terbuat dari ikan disebut hiwan atau iwan 魚丸, 魚 berarti ' ikan' dan 丸 berarti 'benda bulat dan kecil'. 
goreng yang mirip kerupuk.

Ada jenis bahan makanan lain yang dikeringkan, yaitu hici 魚翅, hi 魚 'ikan', dan $c i$ 翅 'sayap', atau hisit 魚翼, hi 魚 'ikan', dan sit 翼 'sayap burung'. Kedua-duanya merujuk pada sirip ikan hiu. Bahan makanan ini tergolong bahan makanan mewah yang biasanya diolah menjadi sup hisit yang mahal harganya. Sebelum diolah lebih lanjut, hisit yang berbentuk potongan sirip ikan harus direndam dulu sampai lunak, setelah itu baru diuraikan. Bahan makanan lain yang dikeringkan adalah udang yang ukurannya kecil-kecil. Udang kecil-kecil yang dikeringkan disebut ebi, hébi 蝦米, he 蝦 'udang', dan $b i$ 米 'beras'. Udang kering atau ebi ini biasanya dihaluskan terlebih dahulu sebelum dipakai untuk bumbu. Selain udang kecil-kecil, ikan cumi-cumi yang ukurannya agak besar juga dikeringkan. Ikan cumi-cumi yang dikeringkan dengan cara dipanggang ini disebut jiuhi atau juhi 鱿魚, $j u$ 鱿 $h i$ 魚 'cumi-cumi'. Juhi panggang yang telah disuwirsuwir biasanya ditaburkan pada masakan yang terbuat dari campuran mi, kentang rebus yang kemudian digoreng, tahu, timun, selada yang disiram kuah bumbu kacang yang diberi perasan jeruk limau. Karena masakan ini di atasnya ditaburi suwiran juhi panggang maka disebut rujak juhi

Ada jenis ikan yang diawetkan, seperti misalnya ikan kakap merah yang dalam Bahasa Tiociu disebut anghi 紅魚, ang 紅 'merah', $h i$ 魚 'ikan'. Karena diawetkan dengan cara diasinkan, maka disebut kiamanghi 鹹紅魚, kiam 鹹 'asin', ang 紅 'merah', hi 魚 'ikan'. Ada pula jenis ikan kecil berduri halus yang dijadikan ikan asin. Ikan asin jenis ini sering digunakan sebagai bumbu penambah rasa asin pada aneka makanan. Ikan yang sudah diawetkan ini disebut pihi 扁魚, pi 扁 'gepeng, pipih', dan hi 魚 'ikan'. Dulu, pihi wajib digunakan dalam pembuatan lunpia Semarang, aneka ca rebung serta masakan berkuah. Sebelum dipakai, pihi digoreng sebentar lalu ditumbuk halus (Marahimin, 2011: 179).

Telur bebek juga diawetkan. Telur bebek yang diasinkan disebut kiamanui 鹹鴨 卵, kiam 鰔 'asin', a 鴨 'bebek', dan nui 卵 'telur'. Ada pula telur bebek atau telur ayam yang dilapisi dengan campuran bubuk kayu, kapur, teh, tanah, dan garam. Kuning telur dari telur yang telah diawetkan berwarna hijau gelap hingga abu-abu, putih telurnya berwarna coklat gelap dan bening, teksturnya kenyal-kenyal dengan sedikit rasa. Telur yang diawetkan seperti ini disebut pitan 皮疍, pi 皮 'kulit', dan tan 疍 'telur'. Telur pitan dapat dimakan begitu saja, atau dicampur dengan masakan lain. Misalnya, telur pitan dipotong kecil-kecil lalu dimasak dengan bubur daging babi. Dalam acara jamuan khusus, telur pitan yang telah diiris disajikan bersama daging babi panggang iris, tiram, acar daun bawang sebagai makanan pembuka. Makanan ini disebut hidangan dingin atau lengpan.

Tahu atau tauhu 豆腐 dalam Bahasa Hokkian atau taofu dalam Bahasa Kanton terdiri dari 豆 'kacang-kacangan', $h u$ 腐 'busuk' adalah bahan makanan yang terbuat dari kedelai putih yang digiling halus-halus, direbus dan dicetak ${ }^{22}$. Tahu merupakan bahan

\footnotetext{
${ }^{22}$ Ada jenis tahu yang berongga di dalamnya setelah digoreng, berbentuk segi empat. Jenis tahu ini disebut
} 
makanan yang sangat dikenal dalam masyarakat Indonesia. Bahan makanan ini dapat diolah menjadi berbagai macam penganan dan lauk. Selain tahu yang berwarna putih, ada pula tahu yang berwarna kuning. Tahu berwarna kuning, bentuknya agak besar dan tidak tebal disebut taokua 豆乾, tau 豆 'kacang-kacangan', dan kua 乾 'kering'. Taokua biasanya dimasak bersama sawi asin atau rumput laut. Selain itu ada taohupoi 豆腐皮, terdiri atas tau 豆 'kacang-kacangan', hu 腐 'busuk', poi 皮 'kulit'. Taohupoi sering disebut kembang tahu ${ }^{23}$. Bahan makanan ini berbentuk lembaran seperti kertas yang digunakan untuk membungkus adonan ayam dan udang sebelum dikukus atau digoreng. Lembaran tipis ini diperoleh dari permukaan susu kedelai yang dipanaskan. Lapisan yang muncul saat susu kedelai dipanaskan diambil dengan lidi yang tebal, selanjutnya dijemur. Kembang tahu dikemas dalam kantong plastik atau kotak plastik yang dapat disimpan lama. Ada lagi sejenis kembang tahu yang berbentuk batangan. Kembang tahu jenis ini disebut dengan taoki atau tauki 豆枝, tau 豆 'kacang-kacangan', $k i$ 枝 'ranting'. Kembang tahu ini biasanya direbus dalam masakan berkuah, misalnya kimlo.

Ada pula biji semangka atau biji bunga matahari yang dikeringkan. Biji semangka atau bunga matahari yang telah dikeringkan disebut dengan kuaci atau koaci 瓜子, kua 瓜 'labu', $c i$ 子 'biji'. Berbeda dengan bahan makanan lain yang biasanya diolah lagi atau dicampur dengan bahan makanan lainnya, isi kuaci yang berwarna putih atau coklat kehijauan dapat dimakan langsung tanpa perlu mengolahnya lagi.

Bakso, baso 肉酥, terdiri atas bak 肉 'daging' dan 酥 (so) 'renyah'. Bakso menurut KBBI adalah makanan terbuat dari daging, udang, ikan yang dicincang dan dilumatkan bersama tepung kanji dan putih telur biasanya dibentuk bulat-bulat. Dengan demikian, bakso dalam Bahasa Indonesia menjadi meluas maknanya menjadi makanan yang tidak saja terbuat dari bak 肉 'daging babi' tapi juga terbuat dari udang, ikan. Namun, seringkali ditambahkan kata 'ikan' untuk yang terbuat dari ikan, menjadi bakso ikan. Begitu pula dikatakan bakso udang untuk yang terbuat dari udang. Selain itu, ada bahan makanan yang berasal dari sejenis kerang laut atau tiram yang disebut pauhi 鮑魚, pau 鮑 'sejenis kerang' dan $h i$ 魚 'ikan', atau dalam Bahasa Latin disebut haliotis gigantea.

Jenis jamur yang sering dipakai untuk campuran masakan adalah hiokow atau hioko 香莎, hio 香 'harum', ko 菰 'sejenis tumbuhan'. Jamur yang bentuknya seperti payung, berwarna putih kecoklatan, biasanya dijadikan komoditi ekspor dalam bentuk makanan kering oleh negara asia timur. Selain jamur hioko, ada pula jenis jamur lainnya yang disebut bokji atau bokni 木耳, bok 木 'kayu', ji, ni 耳 'telinga', atau sering disebut sebagai jamur kuping. Jamur ini tumbuh di kayu-kayu tua, warnanya ada yang putih

tahu pong. Selain lunpia, tahu pong menjadi makanan khas kota Semarang. Beberapa daerah di Sumatra tidak mengenal jenis tahu seperti ini.

${ }^{23}$ Kembang tahu juga mengacu pada penganan yang terbuat dari sari kacang kedelai, kemudian ditambah tepung hunkwe sehingga menghasilkan bentuk yang bertekstur lunak. Kembang tahu dihidangkan dengan saus yang terbuat dari rebusan gula merah dan jahe. 
dan hitam. Baik yang berwarna putih atau yang berwarna hitam keduanya dapat dimasak. Jamur yang putih, setelah direndam sampai lunak, dapat dijadikan campuran minuman es sekoteng Singapura bersama dengan jali, leci, dan biji teratai. Kimciam 金 針, kim 金 'emas', dan ciam 針 'jarum', atau sering disebut sebagai bunga sedap malam sesungguhnya adalah kuncup bunga bakung yang dikeringkan. Biasanya sering dimasak dengan jamur kuping hitam karena warnanya yang kontras sebagai campuran masakan

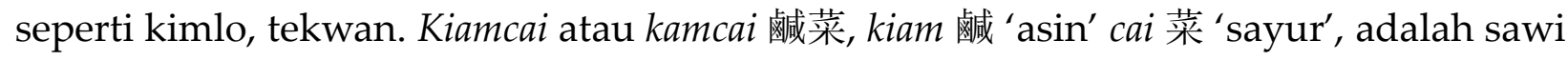
yang bernama latin brassica juncea $L$ yang diawetkan. Mula-mula sawi dijemur di atas tampah, kemudian diremas-remas bersama garam kasar, lalu direndam dalam air tajin (air beras) selama beberapa hari, diperas atau diikat. Karena rasanya yang asin, sawi asin harus dibilas sebentar dengan air sebelum diolah. Sayur asin biasanya dimasak dengan takua atau daging kodok hijau.

Ada pula bahan makanan yang berbentuk panjang-panjang seperti tali, misalnya bihun 米粉, bi 米 'beras' dan hun 粉 'tepung'. Bihun adalah bahan makanan yang terbuat dari tepung beras yang bentuknya seperti mi yang halus. Warnanya putih karena terbuat dari beras 米 bi yang direndam dalam air hingga menjadi bubur kental. Selanjutnya, bubur beras tersebut disaring menjadi bentuk panjang-panjang kemudian dijemur sampai kering. Bihun sering disebut juga sebagai mihun ${ }^{24}$. Kuétiau, kuétiao 粿條, kue 粿 'kue', tiau 條 'ranting', adalah bahan makanan yang bentuknya juga panjang-panjang seperti mi. Kuetiao bentuknya pipih dan lebar, berwarna putih karena terbuat dari tepung beras. Bahan makanan lainnya yang terbuat dari tepung beras seperti bihun atau kuetiao adalah misoa 麵線, $m i$ 麵 'mi', soa 線 'benang', atau misoi 麵細, $m i$ 麵 'mi', soi 細 'halus'. Misoa atau misoi bentuknya juga panjang-panjang seperti mi, tetapi lebih halus dari bihun. Ada pula bahan makanan lain yang bentuknya seperti tali yang terbuat dari tepung terigu, disebut $m i$ 麵 ' $m i$ '. Bahan makanan ini, biasanya dimasak dengan cara digoreng atau direbus, diberi daging, udang, sayuran, bumbu. Bahan makanan lainnya yang bentuknya panjang-panjang yang terbuat dari tepung tapioka atau sagu adalah sohun, soun 索粉, so 索 'sayur', dan hun 粉 'tepung'. Karena terbuat dari tepung tapioka, sohun tidak cepat lembek kalau dimasak. Oleh karena itu, sohun sering digunakan sebagai salah satu campuran masakan berkuah kimlo atau soto. Dengan demikian, bihun, mihun, kuétiau, misoa, misoi, mi, sohun adalah bahan makanan yang memiliki bentuk yang sama, yaitu panjang-panjang seperti tali, tetapi berasal dari bermacam bahan dasar yang berbeda, yaitu beras, gandum, dan singkong.

Hunkué 粉粿, hun 粉 'tepung', dan kue 粿 'kue', adalah bahan makanan yang berbentuk tepung yang terbuat dari kacang hijau. Penganan yang terbuat dari tepung

\footnotetext{
${ }^{24}$ Menurut KBBI, mihun sama dengan bihun. Dalam Bahasa Hokkian, konsonan /b/ dilafalkan sengau, sehingga kedengaran seperti konsonan /m/. Oleh karena itu, bihun kedengaran seperti mihun 麵粉, $m i$ 麵 'gandum' dan hun 粉 'tepung' yang sebenarnya memiliki makna lain, yaitu tepung terigu.
} 
kacang hijau ini juga disebut hunkue. Penganan ini bertekstur lembut seperti agaragar. Selain bahan makanan berupa tepung yang berasal dari kacang hijau, ada jenis tepung lainnya yang terbuat dari akar pakis atau akar teratai. Tepung yang berasal dari akar pakis disebut kiathun 蕨粉, kiat 蕨 'pakis', hun 粉 'tepung', sedangkan yang berasal dari akar teratai disebut liangaohun 蓮藕粉, lian 蓮 'teratai', gao 藕 'akar teratai', hun 粉 'tepung'. Kiathun berwarna kehitaman. Tepung kiathun ini digunakan sebagai bahan pembuat sejenis sohun yang juga berwarna kehitaman. Tepung liangaohun biasanya diolah menjadi bubur. Liangaohun berkhasiat untuk kesehatan kulit.

\section{BUMBU}

Angciu 紅酒, ang 紅 'merah', ciu 酒 'arak 'atau 'arak merah', terbuat dari beras ketan yang difermentasi menjadi alkohol. Jenis arak beras yang rasanya manis dan berwarna kemerahan ini biasanya dipakai untuk memasak. Arak ini digunakan sebagai pemberi aroma untuk tumis sayuran, nasi goreng, mi goreng. Cau 糟 'ampas arak' adalah ketan sisa pembuatan arak yang dipakai untuk penyedap masakan dari daging maupun sayuran. Karena ketan ini basah terendam ragi, maka rasa dan aroma segarnya lebih kuat.

Angco 紅霖, ang 紅 'merah', co 霖 'sejenis kurma', atau kurma cina, biasanya bisa diperoleh dalam bentuk kering. Selain untuk penyedap masakan, terutama masakan yang berkuah, angco juga baik untuk kesehatan tubuh. Angkak 紅粬, ang 紅 'merah', kak 粬 'ragi', adalah beras yang dibiakkan dengan sejenis ragi khusus selama beberapa hari sehingga berubah menjadi merah. Angkak digunakan sebagai bagian dari campuran rempah masakan dan herbal kesehatan untuk menurunkan kolesterol. Belakangan ini angkak sering digunakan untuk menambah darah para penderita demam berdarah. Caipo, caipoh 菜脯, cai 菜 'sayur', dan po 脯 'dendeng', adalah irisan lobak yang diberi garam kemudian dikeringkan. Caipo biasanya digunakan sebagai bumbu penambah rasa asin pada masakan. Tongcai 冬菜, tong 冬 'musim dingin', cai 菜 'sayur', adalah irisan lobak yang diasinkan dan dikeringkan. Tongcai digunakan sebagai penyedap masakan berkuah atau ditaburkan di bubur ayam. Tangkua atau tangkué 冬瓜, tong 冬 'musim dingin', kua 瓜 'labu', adalah labu kuning yang sudah dikeringkan dan diasinkan sehingga warnanya menjadi kecoklatan, kemudian dipotong kotak-kotak. Sama seperti caipo, tangkua juga digunakan sebagai bumbu penambah rasa asin pada

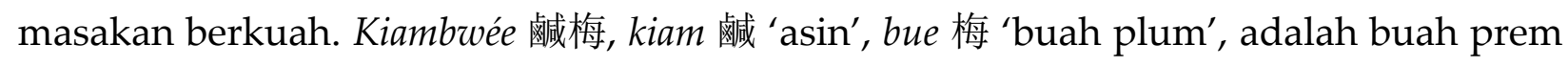
yang diasinkan. Biasanya digunakan untuk menambah rasa segar pada masakan atau jus buah. Lingging-kua 龍眼乾, ling 龍 'naga', ging 眼 'mata', kua 乾 'kering', atau buah kelengkeng yang dikeringkan. Kegunaannya hampir sama dengan kiambwée yaitu menambah rasa sedap pada masakan dan minuman.

Jintan 仁丹, jin 仁 'biji', tan 丹 'merah', adalah biji-bijian berbentuk agak pipih lembut, berwarna kuning kecokelat-cokelatan, berbau sedap, dipakai untuk rempahrempah atau ramuan obat. Pékak八角, pe 八 'delapan', kak 角 'sudut', atau disebut bunga 
lawang, star annise bentuknya seperti bintang, berasal dari polong sejenis pohon yang tumbuh di Barat Daya Cina. Pekak biasanya digunakan untuk bumbu yang memberikan aroma wangi pada makanan Indonesia maupun Cina. Pekak dijual dalam bentuknya yang kering. Ngohiang atau gohiong 五香 ${ }^{25}$, ngo 五 berarti 'lima', hiang 香 berarti 'wangi', digabungkan artinya menjadi lima macam wewangian. Ngohiang sebenarnya adalah aneka bumbu kering, seperti lada, kayu manis, kapulaga, cengkih, bunga pala, bunga lawang, yang dihaluskan dan dicampur menjadi satu. Bumbu ini dipakai untuk bumbu perendam daging yang akan ditumis atau digoreng agar aromanya harum dan sedap.

Selanjutnya, ada beberapa kosakata bumbu masak yang terbuat dari kacang kedelai, misalnya taosi atau taoci 豆豉, tau 豆 'kacang-kacangan' ${ }^{26}$. Taosi merupakan hasil fermentasi kacang kedelai hitam. Biji kedelai pada taosi berbentuk utuh dengan aroma yang tajam menyengat. Meskipun aromanya tajam, tetapi rasanya tidak terlalu asin. Tausi biasanya dijual dalam kemasan botol atau plastik. Hampir sama dengan taosi, ada bumbu lainnya yang juga terbuat dari biji kacang kedelai, disebut taoco atau tauco 豆醬, tau 豆 'kacang-kacangan', co 醬 'saus kental dari kedelai'. Tauco terbuat dari biji kacang kedelai yang telah direbus kemudian dihaluskan dan dicampur dengan tepung terigu. Campuran kacang kedelai halus dengan tepung terigu didiamkan selama beberapa hari lalu dijemur hingga kering. Setelah kering, campuran kedelai diberi larutan garam lalu disimpan lagi selama beberapa minggu. Bumbu ini berwarna kecoklatan dan rasanya agak asin. Biasanya tauco dimasak sebagai bumbu atau penyedap dalam membuat lauk pauk, misalnya ayam bumbu tauco.

Selain itu taosi dan tauco, ada penyedap rasa makanan berbentuk saus yang terbuat dari olahan kacang kedelai. Bumbu atau penyedap masakan seperti ini biasa disebut kecap. Kecap 鮭汁, ke 鮭 'ikan', cap 汁 'sari yang berbentuk cairan' rasanya manis dan sedikit kental karena diberi campuran gula dan rempah-rempah. Kecap yang rasanya manis ini merupakan saus yang penting dalam masakan peranakan. Marahimin mengatakan bahwa masakan peranakan tanpa kecap manis tidak berhak disebut masakan peranakan (2011: 178) ${ }^{27}$. Selain sebagai bumbu, kecap manis juga dipakai sebagai bumbu perendam, saus cocol atau saus siram.

\section{SAYUR-SAYURAN}

Dari daftar kosakata ada sejumlah kosakata yang digolongkan pada sayur-sayuran. Ada sayuran yang tergolong pada jenis sawi-sawian, yaitu caisim 菜心, cai菜 'sayur', sim

\footnotetext{
${ }^{25}$ Umumnya warga keturunan tionghoa dewasa ini juga menyebut ngohiang sebagai makanan yang terbuat dari cincangan daging babi dan berbentuk seperti lumpia berbalut kulit tahu yang digoreng.

${ }^{26} \mathrm{Si}$ atau $\mathrm{ci}$ 豉 tidak pernah muncul sendiri sebagai morfem bebas, selalu berpasangan dengan tau 豆 'kacang-kacangan' menjadi taosi 豆豉.

${ }^{27}$ Kecap aslinya berasal dari Cina dan hanya dikenal kecap asin saja. Selanjutnya, peranakan Tionghoa di Indonesia menambahkan gula dan mengubah ramuannya menjadi kecap manis yang rasanya sesuai selera lokal (Marahimin, 2012: 178).
} 
心 'hati', atau sawi hijau (brassica chinensis), kailan 芥蘭 ${ }^{28}$ sejenis sawi yang batangnya lunak (brassica alboglabra), dan pécai 白菜, pek 白 'putih', cai 菜 'sayuran', sayuran yang daunnya seperti daun lobak atau biasa disebut sawi putih. Ada pula sayuran yang termasuk dalam golongan bawang-bawangan, seperti kucai 非菜29. Kucai (allium adorum) adalah sejenis bawang yang biasanya dimasak sebagai sayur, atau untuk campuran masakan seperti mi goreng atau tumis tahu. Kucai berdaun panjang kecil-kecil berwarna hijau. Lokio 蕗(?) ${ }^{30}$ yang bernama latin allium schoenoprasum adalah tanaman bawang yang dikenal sebagai bawang asinan. Karena rasanya yang gurih pedas, tanaman ini dapat dibuat lalap, sayur bening, sayur asam, atau sebagai campuran hidangan.

Selain jenis sayuran, ada pula jenis umbi-umbian, seperti lobak 蘿葍 ${ }^{31}$ (raphanus sativus) yaitu sayuran yang umbinya berwarna putih, baik umbi maupun daunnya biasa dibuat sayur. Lobak merupakan salah satu campuran masakan soto. Selain lobak, ada singkong 新光, 新 (sing) 'baru', 光 (kong) 'cahaya', yang dalam Bahasa Latin disebut manihot esculenta. Singkong adalah tanaman yang hidup di daerah tropis, umbinya ada yang manis dan ada pula yang pahit. Yang biasa diolah sebagai makanan adalah singkong yang umbinya manis. Yang berumbi pahit biasanya mengandung racun. Daun singkong banyak mengandung protein, biasanya disayur atau direbus sebagai lalap. Tanaman ini sering disebut sebagai ubi kayu.

Selain itu juga ada taogé atau taugé 豆芽, tau 豆 'kacang-kacangan', gé 芽 'kecambah'. Taoge adalah kecambah yang berasal dari kacang-kacangan seperti kacang hijau, kacang kedelai. Taoge banyak digunakan dalam masakan soto, campuran bakwan, dan lain sebagainya.

\section{BUAH-BUAHAN}

Untuk kosakata buah-buahan ada kata angki 紅柿, ang 紅 'merah', $k i$ 柿 'kesemek' atau 'kesemek', lengkeng 龍眼 ${ }^{32}$, leng 龍 'naga', keng 眼 'mata', hing 杏 'aprikot', lai 梨 'buah pir'. Buah pir ini adalah buah yang tumbuh di daerah subtropis, bentuknya seperti jambu monyet, rasanya manis, berair seperti jambu biji (KBBI, 2002: 878). Selain

\footnotetext{
${ }^{28} \mathrm{Kai}$ 芥 tidak pernah muncul sendiri sebagai morfem bebas, selalu berpasangan dengan lan 蘭 'tumbuhan penghasil nila' menjadi 芥蘭 yang mengacu pada sejenis sayuran.

${ }^{29} \mathrm{Ku}$ 非 tidak pernah muncul sendiri sebagai morfem bebas, selalu berpasangan dengan cai 菜 'sayur' menjadi kucai 非菜 yang mengacu pada sejenis sayuran.

${ }^{30}$ Karakter Cina untuk kata lokio belum diketahui (Jones, 2007: 185).

${ }^{31}$ Bak 蓄 tidak pernah muncul sendiri sebagai morfem bebas, selalu berpasangan dengan $l o$ 蘿 'tanaman merambat' menjadi lobak 蘿葍 yang mengacu pada sejenis sayuran.

${ }^{32}$ Kata lengkeng berasal dari bahasa Hokkian dialek Quanzhou, bahasa Hokkian dialek Xiamen menyebut buah yang sama dengan génggéng, bahasa Kanton menyebutnya longan. Ketiganya masuk dalam daftar kosa kata Russell Jones. Dari ketiga kata tersebut kata lengkeng yang diterima menjadi kosa kata bahasa Indonesia.
} 
itu ada pula léci 荔枝 'buah leci'33, putau 葡萄 'anggur' ${ }^{34}$, bue 梅 'buah plum'. Buah plum memiliki daging buah yang tebal, rasanya manis dan mengandung banyak air. Buah plum ini ada yang berwarna hijau kekuningan dan merah keunguan. Buah yang telah matang biasanya dilapisi oleh lapisan putih seperti lilin. Buah ini bermanfaat untuk mengatasi sembelit. Selanjutnya, ada kingkit, kingking, kingkip 金桔, king 金 'emas', kit 桔 'jeruk'(triphasia aurantiola) adalah jeruk yang buahnya kecil-kecil, rasanya masam sekali (KBBI, 2002: 570).

\section{MINUMAN}

$C a$ 茶 dalam Bahasa Kanton atau téh 茶 dalam Bahasa Hokkian adalah pohon kecil yang tumbuh di alam bebas, daunnya berbentuk jorong atau bulat telur, pucuknya dilayukan dan dikeringkan untuk dibuat minuman (di pabrik dsb). Minuman dari tanaman yang bernama latin camellia sinensis inilah yang terkenal di seantero dunia. Di beberapa daerah di Jawa, teh hangat biasanya diminum dengan gula batu atau bénténg 冰糖, bén 冰 'es', téng 糖 'gula'.

Cincau 清草, cin 清 'jernih', cau 草 'rumput' atau dalam Bahasa Latin disebut cyclea barbata sebenarnya adalah tumbuhan yang daunnya dapat diperas menjadi kental untuk isi minuman. Perasan daun yang menjadi kental seperti agar-agar menjadi salah satu campuran minuman dingin. Minuman dingin yang di antara isinya ada semacam agaragar dibuat dari cincau disebut es cincau. Warna cincau ada dua macam yaitu hijau dan hitam. Keduanya jenis cincau ini berguna untuk kesehatan karena dapat mendinginkan perut akibat panas dalam.

Ciu, ciau 酒 adalah minuman keras yang diperoleh dari hasil fermentasi beras. Umumnya arak yang diminum adalah arak putih, sedangkan yang berwarna merah biasanya digunakan sebagai penyedap makanan. Selain minuman yang diperoleh dari hasil fermentasi, ada lagi minuman yang disebut guni 牛奶. Gu 牛 artinya 'sapi', ni 奶 artinya 'susu', kedua makana tersebut digabung menjadi 'susu sapi'. Selain susu sapi, ada susu yang berasal dari olahan kacang kedelai disebut taoni 豆奶, tao 豆 'kacangkacangan', ni 奶 'susu'. Sekoteng 四果湯, se 四 'empat', ko 果 'buah-buahan', teng 湯 'kuah', menurut KBBI adalah sejenis minuman penghangat badan. Minuman ini terbuat dari gula, jahe, tangkue, dsb. (KBBI, 2002: 1014). Selain minuman yang disebut di atas, ada penyebutan untuk es teh yaitu obéng 鳥冰. $O$ 鳥 mengacu pada 'suatu jenis teh', béng 冰 berarti 'es'. Sedangkan otéh 鳥茶, o 鳥 'suatu jenis teh', téh 茶 ‘teh', berarti 'teh tawar'.

\footnotetext{
${ }^{33}$ Le 荔 tidak pernah muncul sendiri sebagai morfem bebas, selalu berpasangan dengan $c i$ 枝 'ranting' menjadi leci 荔枝 yang mengacu pada sejenis buah-buahan.

${ }^{34} \mathrm{Pu}$ 葡 tidak pernah muncul sendiri sebagai morfem bebas, selalu berpasangan dengan tau 萄 'anggur' menjadi putao 葡萄 yang mengacu pada sejenis buah-buahan.
} 


\section{PENUTUP}

Dari uraian singkat di atas terlihat penyerapan kosakata dari Bahasa Cina ada yang mengalami perubahan makna dan ada yang tidak mengalami perubahan makna. Pada kata bakso, bakpia, bakcang, tiongciupia, pangsit, kata bak yang semula merujuk kepada daging babi berubah merujuk kepada daging sapi atau ayam. Hal ini menunjukkan adanya pergeseran makna (meaning). Bak yang semula bermakna daging babi mengalami pergeseran makna menjadi daging bukan babi. Kemungkinan ini disebabkan oleh mayoritas penduduki Indonesia yang beragama Islam. Namun demikian, kebenarannya diperlukan telaah lebih lanjut.

Ada beberapa kosakata tidak disadari lagi bahwa asalnya dari bahasa Cina, misalnya tahu, bihun, soun, bakso, bakmi, kwetiau, pekak, jintan, kuaci, sekoteng, bakpia. Kosakata ini sering digunakan dalam kehidupan sehari-hari oleh masyarakat Indonesia. Demikian seringnya, sehingga tidak terasa lagi bahwa kata ini sesungguhnya berasal dari bahasa Cina.

Makalah ini hanya memaparkan beberapa kosakata yang masih dapat ditelusuri maknanya. Masih ada sejumlah kosakata yang tidak diketahui lagi maknanya karena jarang digunakan oleh masyarakat dewasa ini. Kalau digunakan, hanya terbatas pada lingkungan tertentu. Dengan demikian, perlu suatu penelitian yang lebih mendalam lagi mengenai kosakata serapan yang berasal dari Bahasa Cina.

\section{DAFTAR PUSTAKA}

Chen, Wenxian. Kamus Besar China-Indonesia. Beijing: Pustaka bahasa Asing. 1995.

Hadibroto, Cherry. Indonesian-Chinese Cooking. Jakarta: PT Gramedia Pustaka Utama. 2011.

Jones, Russell (editor). Loan-words in Indonesian and Malay. Leiden: KITLV Press. 2007.

Kridalaksana, Harimurti. Kamus Linguistik. Jakarta: Gramedia. 1982.

Marahimin, Hiang. Seri Masak Femina: Masakan Peranakan Tionghoa Semarang. Jakarta: Gaya Favorit Press. 2011.

Marcus, A.S. Hari-Hari Raya Tionghoa. Jakarta: Penerbit Marwin. 2003.

Nida, E.A. Componential Analysis of Meaning. London: Routledge and Kegan Paul Ltd. 1972.

Pateda, Mansoer. Semantik Leksikal. Jakarta: Rineka Cipta. 2001.

Pusat Bahasa, Departemen Pendidikan Nasional. Kamus Besar Bahasa Indonesia (edisi ketiga). Jakarta: Balai Pustaka. 2002.

Xiamen Daxue Zhongguo Yuyan Wenxue Yanjiusuo Hanyu Fangyan Yanjiushi Zhubian. 1982.

Putonghua Minnan Fangyan Zidian (Kamus Bahasa Mandarin - Bahasa Daerah Fujian Selatan). Fujian Renmin Chubanshe. 